\title{
JOSÉ AgUSTÍN DE LA PUENTE: EL PERÚ COMO ILUSIÓN
}

\section{Francisco Bobadilla Rodríguez,}

José Agustín de la Puente ha fallecido esta tarde a los 97 años. En tiempos como los nuestros que todo se mide en términos de eficacia, la vida de don José Agustín ha sido más bien una vida marcada por la fecundidad: por donde pasó, ha dejado frutos de serenidad, optimismo, unidad, caballerosidad, amor a la patria. Sus investigaciones alrededor de la Independencia y la vida republicana son expresión de su amor al Perú, su gente, su geografía. Habló y escribió más del trigo que de la cizaña. Allí donde veía una espiga de esperanza, celebraba el hecho y la iniciativa. Nunca desalentó ninguna aventura intelectual ni apagó sueños de las nuevas generaciones que acudían a su magisterio.

Admiraba a la Generación del 900. De su magisterio nació mi conocimiento de Víctor Andrés Belaunde y de José de la Riva-Agüero. En una ocasión, a propósito de un conversatorio realizado en la Universidad de Piura en 2014, conmemorando el Centenario del célebre discurso de Belaunde "La Crisis presente" (1914, en San Marcos); don José Agustín dijo que "VAB fue un hombre con criterio amplio, un hombre conciliador. Hay personas que son conciliadoras como Belaunde; otras son de enfrentamiento, de violencia. Belaunde sufría con este estilo humano, pues era un hombre de entendimiento que buscaba los puntos de acuerdo con las personas más distintas e, inclusive, con personas con quienes tuvo polémicas muy duras en su vida”. Don José Agustín tenía este mismo talante amable, acogedor, conciliador; fue un hombre de paz.

Su fineza de espíritu irrigó su hacer y su obrar. Sus escritos sobre historia, sus intervenciones en congresos, sus pláticas en tertulias, sus clases universitarias, sus breves comentarios en pasillos expresaban ilusión humana y esperanza sobrenatural a la vez. Y así se referían a "el Perú como ilusión, no vaga ilusión; sino ilusión retadora para trabajar por su realización". Su optimismo, me parece, se nutría de la virtud teologal de la esperanza, sabedor de que existe un Señor de la historia, que llena de propósito y sentido a la vida humana. De ahí que insistiera una y otra vez en lo importante que es para un pueblo tener una meta común, un objetivo que oriente su trayectoria.

El Perú es lo que ha sido, lo que es y lo que iremos haciendo de nuestra patria, generación tras generación. ¿A qué nos animaría don José Agustín en este tramo de nuestra andadura? A seguir buscando la unidad en medio de la discordia, a comprender que la tarea pública no es un beneficio ni un regalo, sino una obligación vinculante entre

\footnotetext{
* Docente de la Facultad de Ciencias Económicas y Empresariales de la UDEP.

El presente texto es una reproducción del artículo del autor publicado en el diario El Peruano, el 8 de febrero de 2020. También disponible en: http://www.elperuano.pe/noticia-jose-agustin-de-puente-perucomo-ilusion-89594.aspx
} 
Revista Peruana de Derecho Internacional

Tomo LXX Enero-A6ril $2020 \mathcal{N}^{\circ} 164$, pp. 249-250.

ISSN: 2663-0222

la patria y la persona. Gracias, Don José Agustín por el legado de optimismo primaveral que nos deja. 